\title{
I. EDITORIAL
}

O dossiê Vegetarianismo na Antiguidade abre com o artigo de Alexandra Kovacs, A History of Vegetarianism in Antiquity, que apresenta um panorama dos diversos estudos sobre o assunto desde o século XVIII. A autora argumenta que este foi por muito tempo um tema marginal no campo da história e aponta as muitas possibilidades interpretativas oferecidas por uma abordagem histórica do vegetarianismo, especialmente por conta do diálogo da história com a arqueologia. Kovacs também aponta que uma vez que o conceito de vegetarianismo varia de acordo com o tempo, a sociedade e atores em análise, o mais correto seria falar de "vegetarianismos".

O artigo de Alberto Bernabé, Vegetarianismo en la Grecia Antigua, desenvolve a ideia de que não há um único significado para o conceito de vegetarianismo. Assim, o autor argumenta que há uma tendência em se misturar aspectos de formas distintas de vegetarianismo, tanto entre autores antigos quanto modernos. Ele, então, discute algumas vertentes de vegetarianismo na Grécia antiga apontando as diferenças entre elas. Nesse processo, Bernabé coloca especial ênfase no uso político-ideológico da agricultura como força civilizadora associada ao mito de Deméter.

Em Justice for Animals According to Plutarch, Damian Miszczyński argumenta que Plutarco, inspirado pelas tradições pitagóricas e órficas, por um lado, e pela tradição racionalista da Academia Platônica, por outro, criou uma teoria da justiça em relação aos animais. De acordo com essa teoria, a justiça deve ser empregada na relação interespécies, ou seja, a justiça não se restringe ao mundo dos homens, mas se aplica também na relação dos homens com os animais. Nesse sentido, Plutarco parece encorajar sua audiência a reduzir o consumo de carne, a evitar o abuso dos animais como ferramentas de trabalho e a não os maltratar.

Já o artigo de Cintia Alfieri Gama-Rolland, Alimentação e Tabus Alimentares no Egito Antigo: Pode-se Tratar de Vegetarianismo?, analisa fontes textuais, arqueológicas e epigráficas no intuito de investigar se houve o que poderíamos chamar de vegetarianismo entre os antigos egípcios. Nesse sentido, Gama-Rolland contrapõe fontes textuais com evidências da arqueologia e epigrafia no que diz respeito ao consumo de produtos de origem animal e vegetal 
e discute a relação deles com tabus alimentares. Para a autora, os relatos textuais como os de Heródoto e Plutarco, que indicam a existência de tabus alimentares em relação ao consumo de carne, são tardios e parciais e não podem ser generalizados para toda a história do Egito, especialmente por serem consideravelmente desafiados pelas fontes arqueológicas e epigráficas. Assim, a autora argumenta que o único tabu alimentar recorrente na história do Egito Antigo era evitar a fome, tanto no mundo dos vivos quanto no dos mortos, e que, a julgar pela documentação disponível, não houve a prática deliberada de vegetarianismo na Antiguidade egípcia, mesmo que as camadas populares raramente tivessem acesso a alimentos de origem animal.

Para além do dossiê, nós temos três artigos sobre temas variados. O primeiro artigo, Potes, Pratos e Contatos Culturais: Práticas Alimentares na Núbia durante o Reino Novo (c. 1.55o-1.o7o a.C.), da autoria de Rennan Lemos e Fábio Frizzo, faz uma crítica às leituras tradicionais sobre as interações entre egípcios e núbios no mundo antigo apontando o caráter colonialista e racista de tais interpretações, inspiradas anacronicamente nas relações entre europeus e africanos na contemporaneidade. Para tanto, os autores discutem a cerâmica relativa às práticas alimentares produzida na Núbia durante o período do Reino Novo (1.550-1.070 a.C.) à luz da teoria da consubstancialidade das relações de gênero, raça e classe, ressaltando seu potencial de resistência cultural em um contexto de dominação imperial. O segundo artigo, "És Tácito ou Plínio?” (Plin. Ep. 9.23.3.2): Considerações acerca da Aristocracia Senatorial do Período Nerva-Trajanino por João Victor Lanna de Freitas, mostra a dinâmica de inserção e atuação das aristocracias provinciais e municipais no centro do poder político romano através de um estudo da correspondência de Plínio, o Jovem, a Tácito. Já o artigo de Francisco de Assis Sabadini, A Tradição na Produção de Estatuetas Cicládicas (3.200-2.70o a.C.), analisa as estatuetas conhecidas como "tipo canônico" ou "braços cruzados" produzidas pela cultura Keros-Siros nas Cíclades.

Por último, mas não menos importante, nós temos a resenha do livro Against the Grain: A Deep History of the Earliest States (2017) de James Scott por Uiran Gebara da Silva 